\title{
FEASIBILITY STUDY ON THE USE OF FRACTAL ANALYSIS FOR EVALUATING THE SURFACE QUALITY GENERATED BY WATERJET
}

\author{
Andrzej Perec, Frank Pude, Josef Stirnimann, Konrad Wegener
}

Original scientific paper

The paper presents the fractal analysis application for a simple evaluation of the quality of waterjet treated surfaces, especially after abrasive waterjet cutting. This analysis will enable the elimination of subjective assessments of treated surfaces. This will ensure a clear estimate of the quality of the surface and the ability to objectively compare the quality of the cutting edge obtained by using different cutting parameters.

Keywords: fractals analysis; fractal dimension; surface quality; waterjet

Studija izvodljivosti o primjeni fraktalne analize u procjeni kvalitete površina obrađenih vodenim mlazom

Izvorni znanstveni članak

U radu se daje primjena fraktalne analize u jednostavnoj procjeni kvalitete površina obrađenih vodenim mlazom, naročito nakon rezanja abrazivnim vodenim mlazom. Ovom će se analizom omogućiti otklanjanje subjektivne procjene obrađivanih površina. Na taj će se način osigurati točna procjena kvalitete površine kao i mogućnost da se objektivno usporedi kvaliteta odrezanog ruba dobivenog primjenom različitih parametara.

Ključne riječi: fraktalna analiza; fraktalna dimenzija; kvaliteta površine; vodeni mlaz

\section{Introduction}

Treating materials using a high pressure abrasive waterjet is more complex than conventional treatments. High pressure water is converted to a high speed jet inside a nozzle and flows out of the nozzle at a speed of several hundred meters per second, seizes abrasive particles and accelerates them to large kinetic energies.

Table 1 Surface quality levels of aluminium samples, $15 \mathrm{~mm}$ thick [11]

\begin{tabular}{|c|c|c|}
\hline Grade & View & Properties \\
\hline Q1 & $(y)$ & $\begin{array}{l}\text { The cut surface exhibits clear } \\
\text { defects (coarse grooves, } \\
\text { interrupted cuts, scouring, } \\
\text { etc.). }\end{array}$ \\
\hline Q2 & 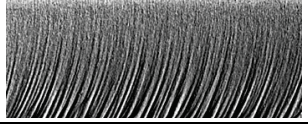 & $\begin{array}{l}\text { Rough cut, with clear, but } \\
\text { regular, grooves without any } \\
\text { gouging }\end{array}$ \\
\hline Q3 & & $\begin{array}{c}\text { Common result, selected for } \\
\text { economic reasons. Grooves } \\
\text { are easily visible. }\end{array}$ \\
\hline Q4 & & $\begin{array}{l}\text { High work piece accuracy } \\
\text { and slight surface roughness. } \\
\text { Slight grooving is visible. }\end{array}$ \\
\hline Q5 & & $\begin{array}{l}\text { Highest shape accuracy of the } \\
\text { work piece and lowest } \\
\text { roughness. No visible } \\
\text { grooves. }\end{array}$ \\
\hline
\end{tabular}

During water jet machining small particles differing in size and shape are detached from the workpiece (micro chipping) as a result of destructive stress concentration in the small volume and as a result of high dynamics. The result of this process is the creation of a surface with characteristic fractures (Tab. 1). The visual appearance and texture of the cut surface can vary widely according to the process parameters $[3,10,13]$ and the materials involved.

Water jet cutting generates qualities of cut surface and accuracies which are categorized in five quality levels
(Tab. 1). These are defined by roughness, angularity deviation, corner deviation, and start and finish defects (Fig. 1). Pressure range, traverse rate and cutting medium (abrasive material with its mechanical properties) have a major effect on the quality level $[4,6]$.

Changing the quality of the surface may occur in a continuous and not discrete way. Therefore, in practice, the determination of the quality of the cut surface is very subjective. The advanced contactless optical shadow method or a contact profilometer could be used to assess the state of the treated abrasive water jet surfaces, [12]. However, in industrial practice there is a need for a simple and not very expensive system to evaluate the quality of the cut surface. For this purpose it was decided to investigate the exploitation of fractal analysis.

\section{Fundaments of fractal analysis technique}

Fractals [8] are of rough or fragmented geometric shape that can be subdivided in parts, each of which is (at least approximately) a reduced copy of the whole. They are wrinkly objects that defy conventional measures, such as length and are most often characterised by their fractal dimension. They are mathematical sets with a high degree of geometrical complexity that can model many natural phenomena. Almost all natural objects can be observed as fractals (coastlines, trees, mountains, and clouds). Their fractal dimension strictly exceeds topological dimension [2].

Fractal analysis means the determination of the fractal dimensions of an image. The fractal dimensions are obtained by using a variation of the Box Counting Method.

The box counting or more precisely "cube counting" estimate for fractal dimension (FD) is also known as the Minkowski-Bouligand dimension or Kolmogorov dimension. The basic idea arises by considering the length, area, and volume of Euclidean objects such as a line, plane, and cube. In one dimension consider a curve 
and a ruler of length $s$. If one counts the number of rulers $N(s)$ required to cover the curve as s decreases then the relationship will be $N(s)$ proportional to $1 / s^{1}$. Similarly in 2 dimensions if we count the number of squares of side length $s$ required to cover a surface then the relationship will be $N(s)$ proportional to $1 / s^{2}$. And finally in 3 dimensions using a cube of side length $\mathrm{s}$ and counting how many such cubes are required to fill a volume the relationship will be $N(s)$ proportional to $1 / s^{3}[1]$.

By using this technique it is possible to examine black and white fractal structures which come into existence during the process called "thresholding" (HarFA). Thresholding transforms coloured image objects into black and white ones. There are many criteria which can be changed to derive many different fractal structures from one image (e.g. the minimal value of hue can be altered to become black threshold, or black can be specified to be all pixels which fulfil the conditions of their RGB channels. It is possible to get various fractal dimensions for one image. If the characterization of an image by its fractal dimension is wanted, it has to be known which of them is appropriate. Therefore it is possible to establish the fractal dimensions of an image in the whole range of thresholding conditions (HarFA Program Tools called: Fractal Analysis - Range). As a result a "fractal spectrum" can be obtained, where the fractal dimension is presented as a function of the thresholding condition (e.g. fractal dimension as a function of masked intensity (shade of grey) value. Fractal spectra and data concerning every data point of the fractal spectrum can be saved and loaded for future viewing as text files.

The determination of the fractal dimensions based on the improved box counting method where binary images of a surface are covered with different grids (box length $\varepsilon$ ), and the number of boxes $N(\varepsilon)$ required to cover the structures of the surface can be recorded. If an object is fractal, $N(\varepsilon)$ increases according to the relation:

$$
N(\varepsilon)=C \cdot \varepsilon^{D},
$$

where: $D$ is fractal dimension, $C$ is constant value.

From this equation the fractal dimension can be obtained as:

$$
D=\lim _{\varepsilon \rightarrow 0}\left\{\frac{\log [N(\varepsilon)]}{\log (\varepsilon)}\right\} .
$$

The Box-Counting method is used for evaluating the fractal properties of abrasive waterjet cut surfaces. The method is often used to determine the fractal box dimension of digitized images of fractal structures.

Nežádal et al. [9] and Buchníček et al. [2] have implemented the Box-Counting procedure in software called HarFA, which was developed at the Institute of Physical and Applied Chemistry at the Technical University of Brno in the Czech Republic. HarFA is able to analyse black and white images.

The Box-Counting method enables the user to cover the fractal pattern with a raster of boxes (squares) and to evaluate how many boxes:

$$
N_{\mathrm{BW}}, N_{\mathrm{BBW}}=N_{\mathrm{B}}+N_{\mathrm{BW}} \text { or } N_{\mathrm{WBW}}=N_{\mathrm{W}}+N_{\mathrm{BW}} \text {, }
$$

of the raster are needed to cover the fractal completely, where: $N_{\mathrm{B}}$ - number of black squares, $N_{\mathrm{W}}$ - number of white squares, $N_{\mathrm{BW}}$ - number of black $\&$ white squares, $N_{\text {BBW }}$ - number of black \& white and black squares, $N_{\text {WBW }}$ - number of black $\&$ white and white squares.

Repeating this measurement with different sizes of boxes $r=1 / \varepsilon$ will result in a logarithmical function of box size $\mathrm{r}$ and the number of boxes $N(r)$ needed to completely cover the fractal. The slopes of the linear functions:

$$
\begin{aligned}
& \ln N_{\mathrm{BW}}(r)=\ln \left(K_{\mathrm{BW}}\right)+D_{\mathrm{BW}} \ln (r) \\
& \ln N_{\mathrm{BBW}}(r)=\ln \left(K_{\mathrm{BBW}}\right)+D_{\mathrm{BBW}} \ln (r) \\
& \ln N_{\mathrm{WBW}}(r)=\ln \left(K_{\mathrm{WBW}}\right)+D_{\mathrm{WBW}} \ln (r) .
\end{aligned}
$$

Give $D_{\mathrm{BW}}, D_{\mathrm{BBW}}$ and $D_{\mathrm{WBW}}$ the fractal dimensions.

$D_{\mathrm{BW}}$ describes the properties of the border of the fractal pattern. $D_{\mathrm{BBW}}$ describes the fractal pattern on the white background and $D_{\mathrm{WBW}}$ describes the fractal pattern on the black background.

\section{Results of analysis \\ 3.1 Fractal analysis of reference surface}

As reference surfaces of roughness profiles 5 surfaces are presented in the proposed ISO standard and are shown in Tab. 1. The fractal dimension calculation results are presented in Fig. 1 to Fig. 6.

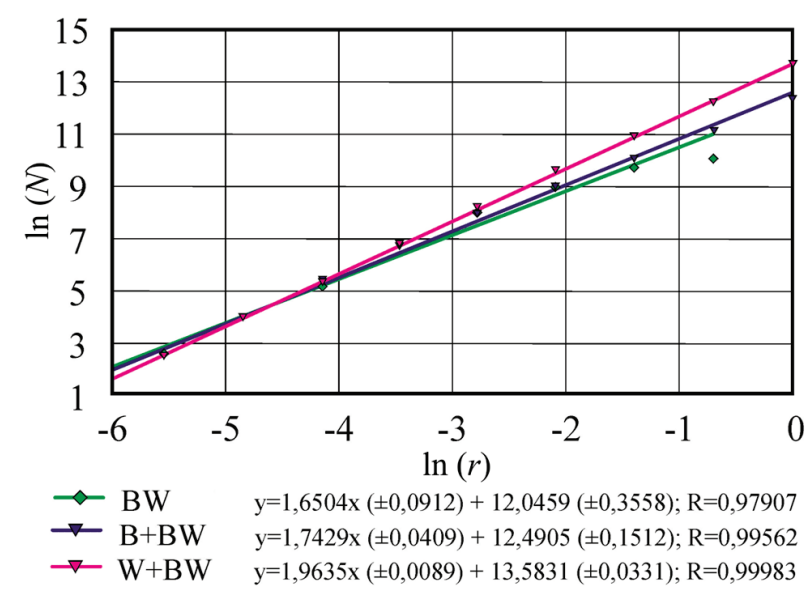

Figure 1 Fractal dimensions for surface Q1 level

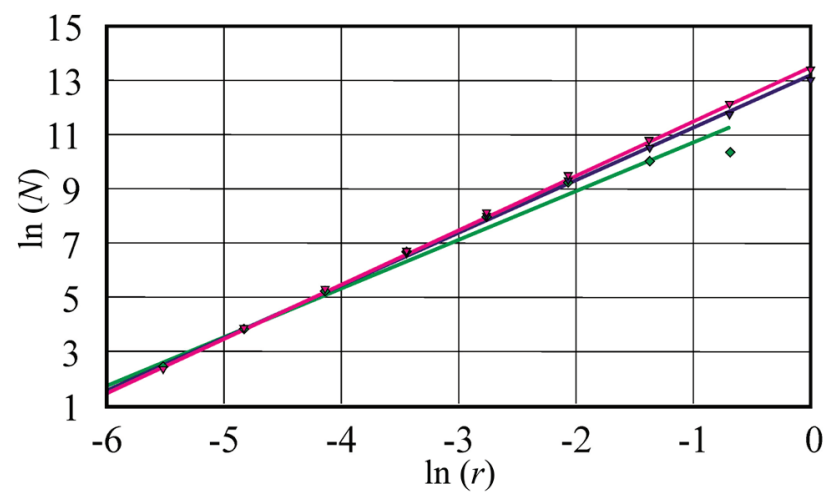

$\prec \mathrm{BW} \quad \mathrm{y}=1,7137 \mathrm{x}( \pm 0,0888)+12,3578( \pm 0,3464) ; \mathrm{R}=0,98154$

$\rightarrow \mathrm{B}+\mathrm{BW} \quad \mathrm{y}=1,8570 \mathrm{x}( \pm 0,0271)+13,0463( \pm 0,1002) ; \mathrm{R}=0,99830$

$\rightarrow-\mathrm{W}+\mathrm{BW} \quad \mathrm{y}=1,9176 \mathrm{x}( \pm 0,0181)+13,3439( \pm 0,0670) ; \mathrm{R}=0,99929$

Figure 2 Fractal dimensions for surface Q2 level 


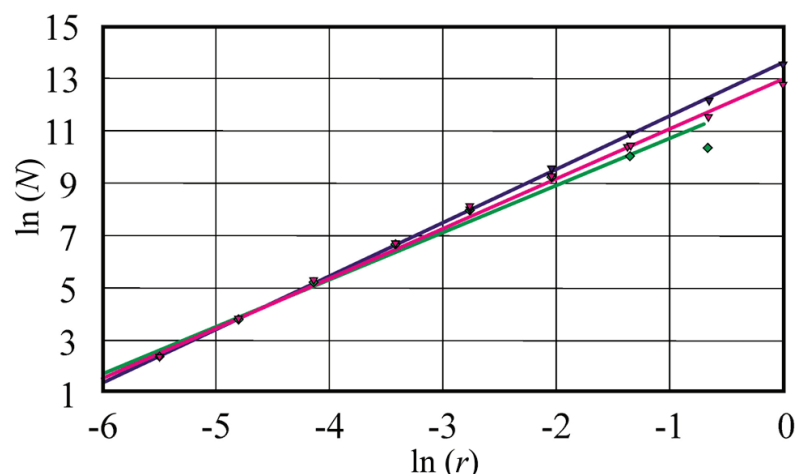

$\diamond \mathrm{BW} \quad \mathrm{y}=1,7219 \mathrm{x}( \pm 0,0888)+12,3866( \pm 0,3465) ; \mathrm{R}=0,98171$

$\rightarrow \mathrm{B}+\mathrm{BW} \quad \mathrm{y}=1,9414 \mathrm{x}( \pm 0,0140)+13,4444( \pm 0,0518) ; \mathrm{R}=0,99958$

$\rightarrow \mathrm{W}+\mathrm{BW} \quad \mathrm{y}=1,8221 \mathrm{x}( \pm 0,0359)+12,8694( \pm 0,1328) ; \mathrm{R}=0,99691$

Figure 3 Fractal dimensions for surface Q3 level

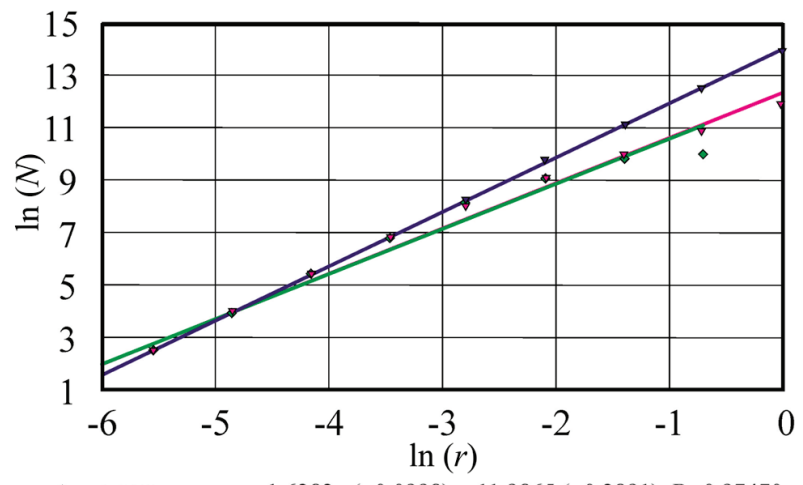

$\neg \mathrm{BW} \quad \mathrm{y}=1,6383 \mathrm{x}( \pm 0,0998)+11,9865( \pm 0,3891) ; \mathrm{R}=0,97470$

$\rightarrow \mathrm{B}+\mathrm{BW} \quad \mathrm{y}=1,9826 \mathrm{x}( \pm 0,0053)+13,6630( \pm 0,0196) ; \mathrm{R}=0,99994$

$\rightarrow-W+B W \quad y=1,6606 x( \pm 0,0623)+12,1036( \pm 0,2305) ; R=0,98887$

Figure 4 Fractal dimensions for surface Q4 level

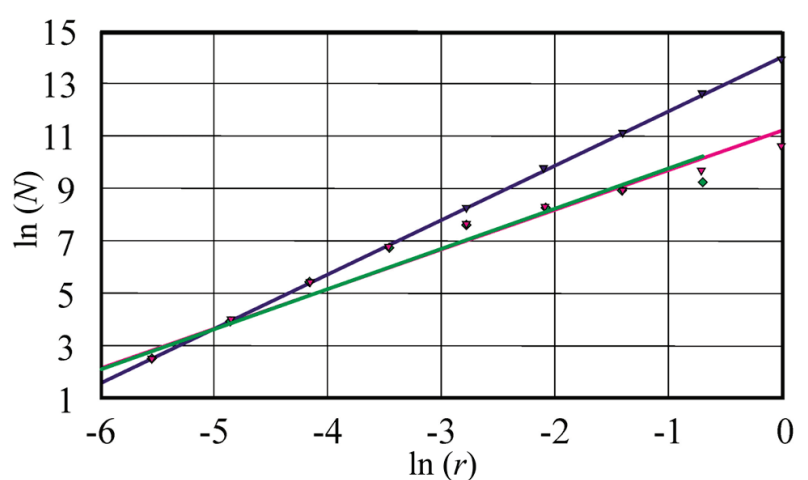

$\curvearrowright$ BW $\quad \mathrm{y}=1,4639 \mathrm{x}( \pm 0,1109)+11,0759( \pm 0,4325) ; \mathrm{R}=0,96139$

$\rightarrow-\mathrm{B}+\mathrm{BW} \quad \mathrm{y}=1,9857 \mathrm{x}( \pm 0,0016)+13,7254( \pm 0,0058) ; \mathrm{R}=1,00000$

$\rightarrow \mathrm{W}+\mathrm{BW} \quad \mathrm{y}=1,4400 \mathrm{x}( \pm 0,0850)+10,9799( \pm 0,3145) ; \mathrm{R}=0,97289$

Figure 5 Fractal dimensions for surface Q5 level

Table 2 Range of fractal dimension values for reference surfaces

\begin{tabular}{|c|c|c|}
\hline \multirow{2}{*}{ Quality level } & \multicolumn{2}{|c|}{ Fractal dimension $D_{\mathrm{BBW}}$} \\
\cline { 2 - 3 } & From & To \\
\hline Q1 & below & 1,800 \\
\hline Q2 & 1,801 & 1,900 \\
\hline Q3 & 1,901 & 1,960 \\
\hline Q4 & 1,961 & 1,990 \\
\hline Q5 & 1,991 & above \\
\hline
\end{tabular}

The values for the reference surfaces were defined on the basis of the dimensional fractal trend line of the interval fractal dimensions (Tab. 2).

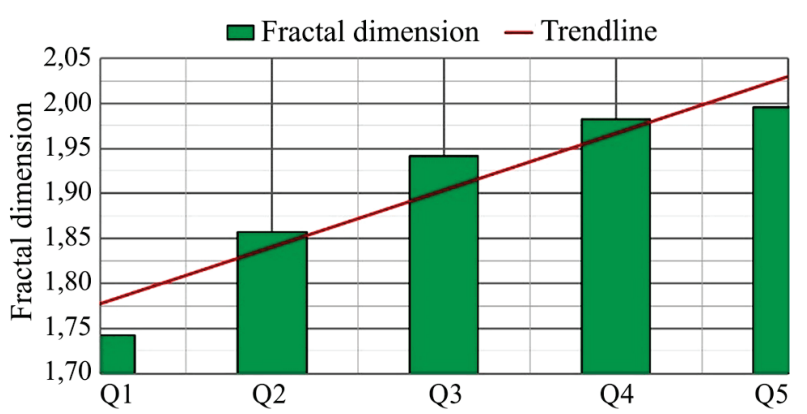

Abrasive waterjetting surface quality

Figure 6 Influence of surface quality after Abrasive Water Jet cutting on fractal dimension

\subsection{Sub area of reference surface}

In order to conduct a deeper analysis each reference area is divided into $3 \mathrm{sub}$ areas: top, middle and bottom (Fig. 7).

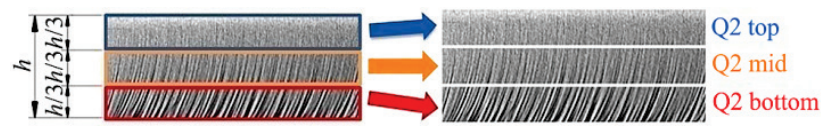

Figure 7 Sample of the sub areas unbundling method on the Q2 reference surface

Each of the sub areas on the sample is subjected to fractal analysis. The results of the analysis are shown in Tab. 2 and Fig. 8.

Table 3 Fractal dimension of reference surface quality level

\begin{tabular}{|c|c|c|c|c|c|}
\hline $\mathrm{D}_{B B W}$ & $\mathrm{Q} 1$ & $\mathrm{Q} 2$ & $\mathrm{Q} 3$ & $\mathrm{Q} 4$ & $\mathrm{Q} 5$ \\
\hline $\begin{array}{c}\text { Fractal dim of } \\
\text { entire area }\end{array}$ & 1,7429 & 1,8570 & 1,9414 & 1,9826 & 1,9957 \\
\hline $\begin{array}{c}\text { Fractal dim of } \\
\text { top area }\end{array}$ & 1,8299 & 1,9343 & 1,9779 & 1,9880 & 1,9968 \\
\hline $\begin{array}{c}\text { Fractal dim of } \\
\text { mid area }\end{array}$ & 1,6889 & 1,8219 & 1,9429 & 1,9866 & 1,9948 \\
\hline $\begin{array}{c}\text { Fractal dim of } \\
\text { bottom area }\end{array}$ & 1,6753 & 1,7853 & 1,8935 & 1,9714 & 1,9948 \\
\hline
\end{tabular}

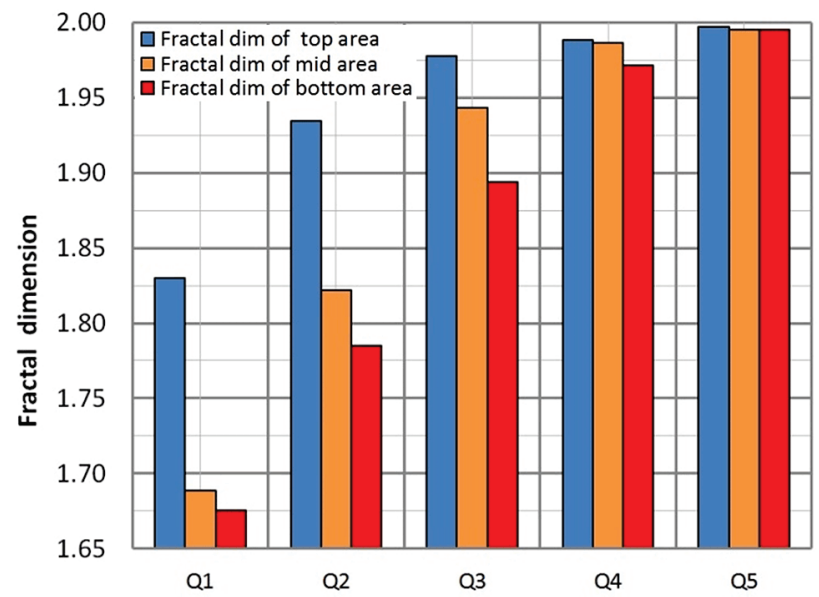

Abrasive Waterjetting Surface Quality

Figure 8 Fractal dimension of reference surface sub areas

In the case of surface qualities Q1, Q2 and Q3, a clearly larger fractal dimension for the area at the top of samples (framed blue) can be observed. In the central part of the surface (framed orange) the fractal dimensions are close to the average value. For the lower part (framed red) the fractal dimension values are the lowest. 


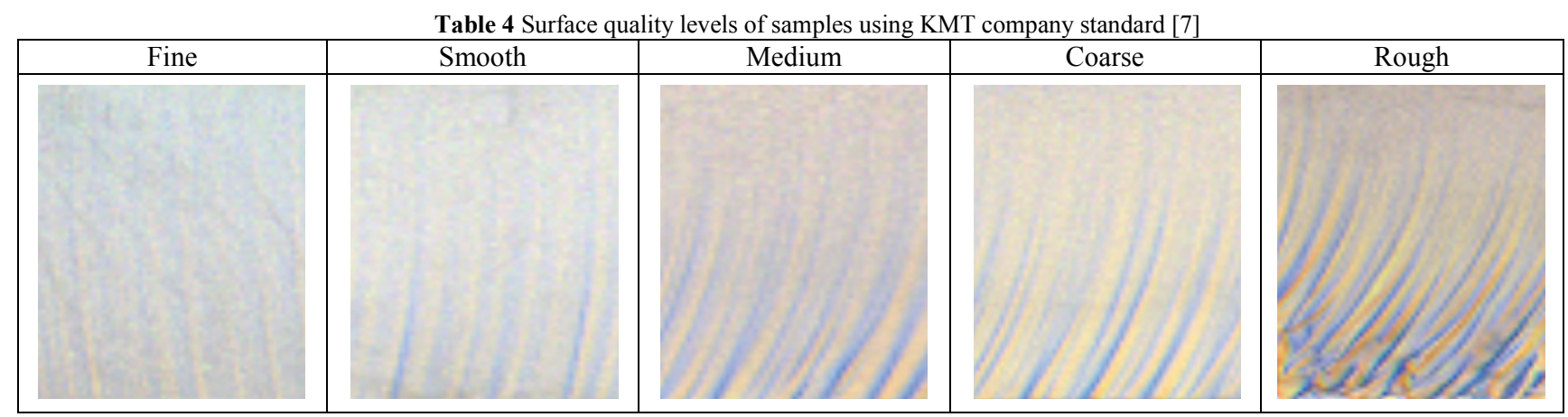

For the Q4 and Q5 surface qualities, low diversity of fractal dimension on separate subareas can be observed.

\section{Verification}

To verify the fractal analysis fractal dimensions were tested for water jet cut surfaces generated by using technology parameters recommended by the American company KMT Waterjet (Tab. 4). The results of the comparison are shown in Fig. 9.

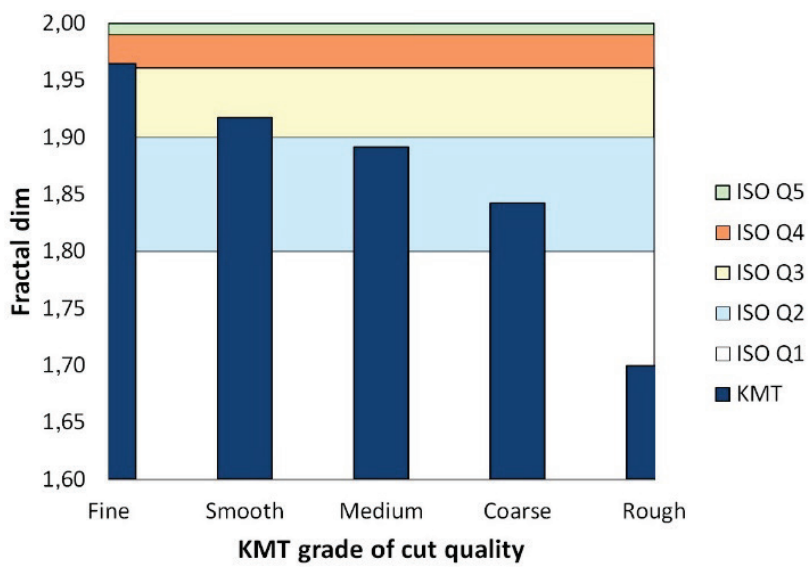

Figure 9 Fractal dimension of surfaces recommended by KMT Waterjet in relation to range of fractal dimension calculated on basis of ISO qualities

In the rough and coarse surface quality there is good compatibility for the quality of the surface and the fractal dimension. Medium intersection in quality, recommended by KMT is almost (difference is below 0,017) consistent with the range of fractal dimensions calculated on the basis of ISO/TC $44 \mathrm{~N} 1770$ proposal standard.

For smooth and fine surfaces a comparison of fractal dimensions is less consistent.

\section{Conclusion}

Based on fractal analysis the following conclusions were drawn:

- Fractal dimension can be helpful for characterizing the surface quality of waterjet machined cutting edges.

- The fractal dimension of the analysed areas is in the range $1,67 \div 1,99$. It can serve as a technological parameter characterizing the treated workpiece surface. Changing the treatment causes a change in the value of fractal dimension.
- The fractal dimension of the poor quality surface is highly variable in sub areas.

- The fractal dimension of the high quality surface has little differentiation in sub areas.

- Due to the changing qualities of the photographs used, the calculated fractal dimensions may vary in an uncontrolled range. This dependency has to be identified (quantified) and correction parameters have to be implemented in future research.

- For using this method it is absolutely necessary to ensure that the whole surface area (from top to bottom of the cutting edge) is displayed in the photograph used. Due to changes of surface roughness properties along the jet flow direction (from top to bottom of the cutting edge) a separated or zoomed sub area will change the outcome of calculations and give wrong results.

- The next step in this simple method is to quantify the influence of a photo's optical properties such as resolution, contrast, white balance, etc. on fractal dimensions. This way the limitations of the fractal analysis method can be recognized.

Notice: This paper was presented at 3. Mezinárodní konference $/ 3^{\text {rd }}$ International Conference Solán̆, Karolinka, 2013.

\section{References}

[1] Bourke, P. Box counting fractal dimension of volumetric data, http://paulbourke.net/fractals/cubecount (1.07.2014)

[2] Buchníček, M.; Nežádal, M.; Zmeškal, O. Numeric Calculation of Fractal Dimension. // Nostradamus 2000 , Proceedings of Prediction Conference, Zlin, 2000, pp. 10-15.

[3] Chomka, G.; Chudy, J. Analysis and interpretation of measurements of surface machining effectiveness in the process of varnish removal by a water-ice jet. // Tehnicki vjesnik-Technical Gazette. 20, 5(2013), pp. 847-852.

[4] Guo, N.-S. Schneidprozess und Schnittqualität beim Wasserabrasivstrahlschneiden. // Fortschritt-Berichte VDI, Reihe 2: Fertigungstechnik, Nr. 328, / VDI-Verlag, 1994.

[5] HarFA - Harmonic and Fractal Image Analyser, Software for Determination of Fractal Dimension, http://www.fch.vutbr.cz/lectures/imagesci (1.07.2013)

[6] Holka, H.; Matuszewski, M.; Musial, J.; StypRekowski, M. Tribological aspects of some materials abrasive-water jet cutting. // Journal of Machine Engineering. 12, 2(2012), pp. 46-53.

[7] KMT Waterjet Calculator for Cutting Speeds. http://www.kmtwaterjet.com/kmt-cut-calculator (1.07.2013). 
[8] Mandelbrot, B. The Fractal Geometry of Nature. W.H. Freeman, San Francisco, 1983.

[9] Nežádal, M.; Zmeškal, O.; Buchníček, M. The BoxCounting: Critical Study. // Proceedings of $4^{\text {th }}$ Conference on Prediction, Synergetic and more ..., Zlin, 2001.

[10] Perec, A. The surface properties of constructional materials with the high-pressure, hydroabrasive waterjet cutting. // Proceedings of XXIV Scientific School of Abrasive Machining, Lopuszna, 2001, pp. 137-144.

[11] Standard proposal: ISO/TC $44 \mathrm{~N}$ 1770, 2010 http://standardsproposals.bsigroup.com/Home/getPDF/ 392, (1.07.2013)

[12] Innovative Algorithms and Techniques in Automation, Industrial Electronics and Telecommunications 2007. // Povijest knjige / Valíček, J.; Hloch, S.; Držík, M.; Ohlídal, M.; Mádr, V.; Lupták, M.; Fabian, S.; Radvanská, A.; Páleníková, K. Study of Surfaces Generated by Abrasive Waterjet Technology. Dordrecht: Springer Netherlands, 2007, pp. 181-185.

[13] Problems of Mechanical Engineering and Robotics. // Povijest knjige / Quality of workpiece in high pressure WaterJet treatment. / Wantuch, E. Krakow: AGH, WIMiR, 2012, pp. 221-236.

\section{Author's addresses}

Andrzej Perec, Dr.-Ing.

Inspire - Competence Center for Mechatronic Systems and Manufacturing Technology ETH Zürich,

Department of Micro Machining, PFA H16

Technoparkstrasse 1, CH-8005 Zurich, Switzerland

E-mail: perec@inspire.ethz.ch

\section{Frank Pude, Dr.-Ing.}

Inspire - Competence Center for Mechatronic Systems and Manufacturing Technology ETH Zürich,

Department of Micro Machining, PFA H16

Technoparkstrasse 1, CH-8005 Zurich, Switzerland

E-mail: pude@inspire.ethz.ch

\section{Josef Stirnimann, Dipl.-Ing.}

Inspire - Competence Center for Mechatronic Systems and Manufacturing Technology ETH Zürich,

Department of Micro Machining, PFA H26

Technoparkstrasse 1, CH-8005 Zurich, Switzerland

E-mail: stirnimann@inspire.ethz.ch

\section{Konrad Wegener, Prof. Dr.-Ing.}

Inspire - Competence Center for Mechatronic Systems and Manufacturing Technology ETH Zürich and Institut für Werkzeugmaschinen und Fertigung

ETH Zentrum, CLA G5

Tannenstrasse 3, CH-8092 Zürich, Switzerland

E-mail: wegener@iwf.mavt.ethz.ch 